\title{
Different beliefs and teaching vocabulary: Memory-based V.S Function-based beliefs
}

\author{
Mozhgan Alsadat Ghaffarzadeh Hassankiadeh
}

Islamic Azad University, Tonekabon Branch, Iran

\section{Email address:}

Ghaffarzadeh.mail@gmail.com

\section{To cite this article:}

Mozhgan Alsadat Ghaffarzadeh Hassankiadeh. Different Beliefs and Teaching Vocabulary: Memory-Based V.S Function-Based Beliefs. International Journal of Language and Linguistics. Special Issue: Language Teaching and Learning Key Principles (LTLKP).

Vol. 1, No. 4-1, 2013, pp. 11-19. doi: 10.11648/j.ijll.s.20130101.13

\begin{abstract}
Teachers' ideas, their views of the world, their values and conceptions of their environment will affect seriously on their actions in the classroom. And these actions consequently will lead to some reactions in learners which cannot be separated from those of teachers. So based on the importance of these insights and views, the current paper investigates the effects of language teachers' beliefs on learners' intake in language learning classrooms. Among different areas of language learning, vocabulary was selected to examine because of its significant role in learning to communicate through language. So the research attempts to identify which one of the teachers' lexicon teaching beliefs is more effective in enhancing learners' vocabulary intake. The beliefs which are under question are divided into two groups: Memory-based and Function-based beliefs about teaching lexicon. The purpose of the study is to examine the effects of teachers' actions (closely related to their stated beliefs) on learning vocabulary by Iranian EFL learners. 100 learners and their teachers were selected randomly based on Morgan's table for sampling. The findings indicate that: a) the learners who were taught by teachers that placed more emphasis on function-based beliefs are more successful in learning lexicon than those who were taught by teachers focusing more on Memory-based beliefs; $b$ ) the result is the same for both genders.
\end{abstract}

Keywords: Memory-Based Beliefs, Function-Based Beliefs, Teaching Lexicon, Vocabulary Intake, Teachers' Beliefs

\section{Introduction}

It is certainly not new that prospective teachers bring with themselves many beliefs about the nature of teaching and learning and that these beliefs interact with the content and pedagogy of their teaching procedures (Anderson and Bird, 1995; Borko, Eisenhart, Brown, Underhill, Jones, and Agard, 1992; Calderhead, 1991; Calderhead and Robson, 1991; Kagan, 1992; Pajares, 1993; Wubbels, 1992) and influence what and how they teach. Similarly this study investigates the effects of different teachers' beliefs about teaching lexicon on learners' vocabulary intake. The study of teachers' beliefs forms a part of the process of understanding how teachers conceptualize their work (Ghaffarzadeh (b), 2012). In last two decades, teacher education research has made significant advances in studying teacher beliefs, and the connection between teacher beliefs and educational practice has already been well established (Borg, 2003; 2012). In short, how teachers have seen and experienced learning/teaching can be an important problem in learning/teaching field because it shall affect their beliefs and subsequent actions in teaching situations.

Learning lexicon is one of the most important domains in the process of learning a language for the aim of communicating and should be considered as significant part of teaching and learning languages too. About its significance in learning a language it can be said that limited knowledge of English vocabulary may affect the school performance of English language learners (Cummins, 1994). During the past decade, researchers and academics have pointed to the importance of vocabulary acquisition for second language (L2) learners (Allen, 1983; Laufer, 1986; Nation, 1990; Richards, 1980). But there has been little or no well-prepared research about the effect of teachers' beliefs on their learners' vocabulary learning. In this study, the aim is to fill this gap and to investigate the relationship between teachers' beliefs and learners' amount of lexicon intake. Studying lexicon teaching beliefs will assist us to educate will be going teachers in a way that can 
help them to explore more helpful beliefs in promoting learners' lexicon intake. So the current study aims at investigating this relationship to assist in solving some problematic areas in learning/teaching languages.

\section{Teachers' Beliefs and Teaching Lexicon}

Richards, Gallo \& Renandya (2001) have stated that beliefs were found to be far more influential than knowledge in determining how individuals organize and define tasks and problems, and were better predictors of how teachers behaved in the classroom than other factors. And as Rifkin (2000) explained Teachers' beliefs about the learning/teaching process are "of crucial importance to the success or failure of learners' efforts to master a foreign language" (p. 394). Horwitz (1985) also in harmony with previous statements concluded that teachers' belief is a central construct which deals with human behavior and influence teachers' consciousness, teaching attitude, teaching methods, teaching policies, teaching behavior and learners' development . During past 20 years, a lot of researches were done about different learning beliefs (cf. Brookhart\& Freeman, 1992; Chan \& Elliot, 2004; Minor, Onwuegbuzie, Witcher, \& James, 2001; Ozgun-Koca \& Sen, 2006), as well as teachers' self-efficacy beliefs (Brand \& Wilkins, 2007; Palmer, 2006) and their diversity beliefs (Milner, 2005; Pohan \& Adams, 2007). Different teachers' beliefs were under questions in a lot of researches like those ones which focused on pedagogical beliefs in particular. Theses researches suggests that many beginning teachers view teaching as telling or lecturing that is, directly transmitting information to a passive learner (Brookhart\& Freeman, 1992; Holt-Reynolds, 1992; Richardson, 1996; Torff, 2003). In fact, As ghaffarzadeh(b) (2012) concluded different teacher beliefs will lead to different ways of classroom management, different teaching strategies, different practices and subsequently differences in the amount of learner intake".

Vocabulary learning is considered as a crucial task for second language learners in their attempts to improve linguistic competence (Brown \& Perry, 1991; Gu, 2003, 2005).Research suggests that vocabulary is enormously important to children's development, especially in reading (Ghaffarzadeh (b), 2012). Research clearly indicates that children with larger vocabularies have higher school achievement in general (Smith, 1941, cited in Beck, McKeown, \&Kucan, 2002).

As indicated in the studies cited on teaching beliefs, exposure to different learning/teaching strategies will lead to different beliefs and consequently to different behaviors in the classroom. Considering this significance, the present article first outlines the differences between teaching beliefs concerning memory-based and function-based vocabulary teaching in learning/teaching situations.

\subsection{Memory-Based and Function-Based Teaching Beliefs}

In this research, the focus is on two kinds of teachers' beliefs about teaching vocabulary that will be called memory-based and function-based. Memory-based belief refers to concentrating on memorizing words, analyzing the parts of speech, focusing on affixes, listening and repeating, writing and practicing, imagining the written forms of the words and connecting the words with their synonyms and antonyms( Ghaffarzadeh (b), 2012). Teachers in this group believe that using keyword methods to memorize the words such as mnemonics, concentrating on the form of the words and using strategies to remember them (without direct attention to meaning) is an effective teaching approach to vocabulary learning. Helping you to imagine the beliefs in your mind: supposing that a teacher wants to teach the word "careless", memory-based teaching implies that the teacher may use a list of the words which are in the same family with the selected word, synonyms or antonyms or even words derivations or affixes (such as carelessly, careful, -full, less, ...) and then ask the learners to repeat and memorize them.

In contrast Function-based belief refers to the negotiation of meaning through the application of words in sentences and texts, or through activities that help the learner understand the targeted words better and to make relationships between the words and the learners' own experiences (Ghaffarzadeh(b), 2012). The teachers in this group may ask the learners to play some roles of some stories about driving, writing, washing, and .... carelessly or may tell a story about his/her own experiences that was because of doing something carelessly. Or he/she may simply push a student, apologize and say I am a careless person Are you, too? Such sequences will lead learners to learn through acting. In other words, it is an approach that uses the learners' energy for learning instead of just imagining the words (Ibid, 2012).

\subsection{Data Gathering: Subjects}

The raw data derived from the participation of 100 English as Foreign Language junior high school learners (Guidance School grade 3 in Iran) ${ }^{\text {a }}$ both male and female, and two teachers. Both of them declared their consents to participate in the research. Subjects were selected out of approximately 160 EFL students in the same grade in junior high schools in Nowshahr, Mazandaran, Iran. All of 100 students who were chosen began the academic year at the same level of language proficiency when they were determined in homogeneous groups (Memory-based \& Function-based groups) by utilizing OPT b. So, 100 homogenous participants were divided into two groups participating 50 members in each one.

Two teachers (one for Memory-based and one for Function-based group) were selected to participate in the study. Learners' selection was randomly based on the Krejeie and Morgan's c table for identifying the number of samples from a statistical community. In selecting the 
teachers the story is different. Because the research needs some special teachers with some specific beliefs, $30 \mathrm{EFL}$ teachers out of 50 were selected randomly and were asked to participate in the research by filling in a teaching belief questionnaire and then two out of this thirty were chosen for the study, based on their answers to the questions (their beliefs). In other words two teachers who obtained the highest score in items of the questionnaire belonging to categorized beliefs (Memory-based \& Function-based) were selected to participate in the process of researching in main groups. In fact the one who scored highest by indicating beliefs in memory-based strategies for teaching was selected to represent the teacher of the memory-based group and the teacher who scored highest in Functionbased strategies (beliefs) for teaching was selected to represent the teacher of the Function-based group (see appendix A, the questionnaire of vocabulary teaching beliefs).

\section{Instruments: Teachers' Beliefs Questionnaire, OPT and Vocabulary Test}

\subsection{Questionnaire}

A questionnaire is utilized in this research to illustrate teaching beliefs about lexicon in teachers' minds. As Horwitz (1985) mentioned a questionnaire is a beneficial tool for data collection in studies on mental aspects like beliefs (Horwitz, 1985). The questionnaire was used for categorizing the teachers into different groups here. And it was followed by a vocabulary test which was given to the learners who had been taught by these teachers as an instrument to identify the amount of learning and the results of teachers' beliefs. The questionnaire was chosen because as Dörnyei (2003) declared "by administering a questionnaire to a group of people, we can collect a huge amount of information in less than an hour".

The questions in the questionnaire derived from a previous survey of 30 EFL teachers (selected randomly from Nowshahr and Chaloos, two cities in Mazandaran, Iran) that in which the teachers were asked to write their beliefs about teaching lexicon anonymously. Then they were used as sources for designing the questionnaire. Then they were evaluated and modified by seven experienced, Iranian EFL teachers to guarantee the appropriateness of the categories in measuring lexicon teaching beliefs in Iranian learning contexts. The categories fell within the boundaries of memory-based and function-based beliefs for teaching lexicon.

Ten experienced Iranian EFL teachers (different from those ones who had evaluated the questionnaire for appropriateness) to mark the questionnaire to confirm its reliability and validity. The content validity was equal to $87 \%$. Following this, the questionnaire was given to a group of teachers to fill it to identify the reliability; using
Cronbach's Alpha, the reliability was estimated as93\%. And these results let the researcher conclude that the questionnaire was appropriate for use in the research as a tool to measure teachers' beliefs concerning teaching / learning lexicon. $98 \%$ of teachers' beliefs represented in the study were derived from a survey of teachers of Nowshahr and Chaloos (two cities in Mazandaran, Iran). The other $\% 2$ was neglected because they weren't organized strategies or beliefs.

\subsubsection{Memory-Based Group Questions}

Respondents who responded affirmatively to questions 2 , 5, 6, 7, 8, 10, 11, 12, 16, 17, 19, 20 and 24 (see Appendix A) were assigned to the memory-based group. In fact they concentrate on memorizing words, analyzing the parts of speech, focusing on affixes, listening and repeating, writing and practicing, imagining the written forms of the words and connecting the words with their synonyms and antonyms(Ghaffarzadeh (b), 2012). The beneficial techniques are keyword methods, mnemonics, concentrating on the form of the words and using strategies to remember the words with minimum attention to understanding the meaning of the word here.

\subsubsection{Function-Based Group Questions}

And Respondents who replied affirmatively to questions $1,3,4,9,13,14,15,18,21,22,23,25$ and 26 (see Appendix A) were put in function-based group . These believers believe on connecting the words with reality and learners' experiences, making use of common sense and knowledge of the world, using real objects such as reading newspapers or a book and using words in real-life or quasireal life situations(Ghaffarzadeh (b), 2012). To group words within a storyline form, to use physical actions to learn vocabulary, get learners to do specific actions and feel free in learning situations were covered in this part.

\section{2. $O P T$}

It is the initial test which was used in order to group the learners, homogeneously, in the groups to guarantee the reliability of the research method. This test was utilized as a tool to be able to measure the effect of independent variable (lexicon teaching beliefs) on the dependent variable (learners' vocabulary size). Based on this test the proficiency level of learners will be determined to assist researcher in relying more on the results.

\subsection{Vocabulary Test}

Harrison (1983) believed vocabulary testing is believed to be a useful element in a teaching program, providing teacher and learner with useful information that can serve each as a basis for improvement. The goal of utilizing a vocabulary test in this study was to measure the learners' progress in learning vocabulary and aim at helping to analyze these results considering their teacher's beliefs about teaching/ learning lexicon. 


\subsection{The Form of the Vocabulary Test}

The test consisted of 42 words that the students had to define, without any previous preparation for the exam. The test was given to the learners after they had been taught by the teachers for approximately six months after the initiation of the study. It was based on the syllabus of Iranian EFL learners who were in grade three in senior high schools in Iran (using the textbook of the grade as the reference for constructing the test). The learners were asked to write the meanings of the words in English or Persian. They should learn up to 160 words when the exam will be given. This huge burden of lexicon learning is due to their syllabus and based on the political areas of educational ministry of Iran and the researcher had no role in choosing it.

\section{Pilot Study}

A Pilot study was used in this research for the purpose of promoting the appropriateness and measuring abilities of research instruments based on what Ghaffarzadeh (2012) stated "Despite the most careful planning, there is no guarantee that a research project will work well in practice.
This pilot study was utilized to omit any vague or incorrect questions which may confuse participants. As Allison et al (1996, p.95) stated: "For this purpose you need people who are of ability and background similar to your target population, The pilot subjects were selected from Chaloos, Mazandaran, Iran who are as similar as target group. The comparison of pilot study and final study can be seen in Appendix C well.

The results of the pilot study which was given to 16 learners and two teachers is as following: the vocabulary learning promotion of the students who had a teacher in function-based group was better than those students in the group of the Memory-Based teacher.

\section{The Procedure}

After the results of the OPT were collected the teachers were categorized into two groups based on their answers to the questionnaire. In this study, T-test was used to identify the answer to the research question. Each of the groups of beliefs had 13 items. The total number of items in this questionnaire was 26. The responses of EFL teachers that were given to the questions are shown in table 1.

Table 1. First teacher's answers to each part of the questionnaire

\begin{tabular}{ccccccc}
\hline & & & Teacher1 & & \\
& & not at all useful \\
Count & slightly useful & count & moderately useful & Count & quite useful \\
Count & Count \\
\hline \multirow{2}{*}{ belief } & Memo-B & 10 & 2 & 1 & 0 & 0 \\
& F-B & 0 & 0 & 1 & 2 & 10 \\
\hline
\end{tabular}

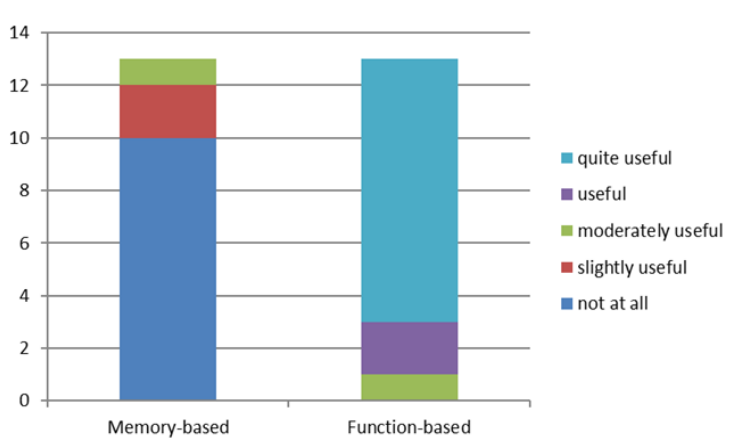

Graph 1. First teacher's answers to each part of the questionnaire

Based on the data in table 1 and the graph 1 for this teacher which is presented here, it was concluded that the teacher 1 believes more in Function-Based lexicon teaching because this teacher's negative answers to the group of questions associated with Function-Based group are the lowest and his positive answers to this group are the highest. The mean value of each part of the beliefs in this questionnaire is 39 . Using the formula of " $5 * 13+13 / 2$ " for calculating the marks in the questionnaire based on a Likert scale, If the teacher's answers are superior to this value, it indicates positive beliefs and if it is below the value it shows negative beliefs.

According to table 1, the first teacher's mark in memorybased teaching is 17, and in Function-Based, his mark is equal to 61 . The scale values are not at all $=1$, slightly useful $=2$, moderately useful $=3$, useful $=4$, and quite useful $=5$. As it can be seen, $17<39$, whereas $61>39$, so it can be concluded that first teacher's beliefs about MemoryBased are more negative than Function-Based teaching. In other words this teacher's belief is positive toward Function-based(F-b) and negative for Memorybased(Mem-b) ones.

Table 2. Second teacher's answers to each part of the questionnaire

\begin{tabular}{llllll}
\hline & not at all useful & slightly useful \\
& & Count & $\begin{array}{l}\text { Teacher2 } \\
\text { moderately useful } \\
\text { Count }\end{array}$ & $\begin{array}{l}\text { useful } \\
\text { Count }\end{array}$ & $\begin{array}{l}\text { quite useful } \\
\text { Count }\end{array}$ \\
\hline \multirow{2}{*}{ belief } & Memo-B & 0 & 0 & 1 & 2 \\
& F-B & 10 & 2 & 1 & 0 \\
\hline
\end{tabular}


Based on the data in table 2 and the graph 2 for this teacher, it was concluded that second teacher believes more on Memo-b lexicon teaching beliefs. His negative answers to Memo-Based questions group are the lowest and his positive answers to this group are the highest.

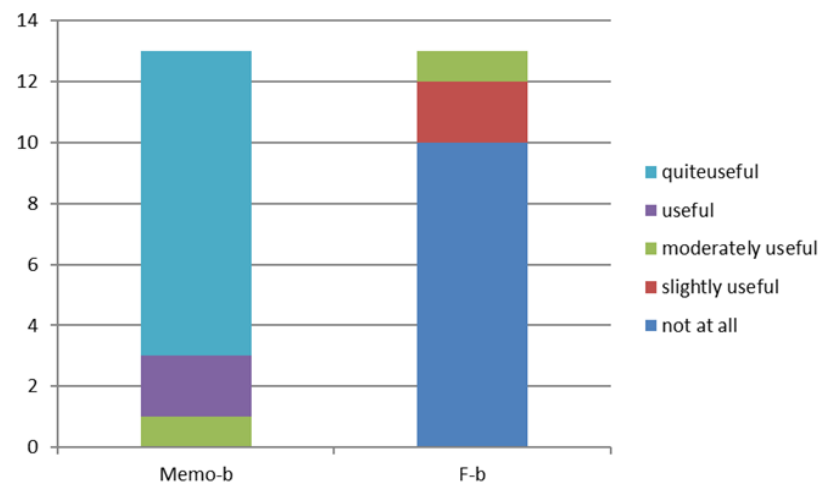

Graph 2. Second teacher's answers to each part of the questionnaire

As can be seen in table 2, this teacher's mark in Memory-Based questions is 61 and in Function-Based is 17. 17 is less than 39 and 61 is greater than 39 , so this teacher believes less in Function-Based teaching than in MemoryBased teaching. So second teacher was classified in the group of Memory-Based beliefs.

\subsection{Organizing Learners in the Groups}

After organizing the teachers in the groups based on their beliefs it is the time of categorizing learners in groups too. Learners were distributed equally according to level (all scored similarly in the OPT) and gender (25 members for each gender in each group). After six months of normal classes (the teaching is as like other courses, nothing was changed), the learners would give the meanings of 42 words (they could define in English or Persian) to enable the researcher to test their promoting vocabulary knowledge. As stated before the Students did not know about the test beforehand. Correct answers were utilized as criteria for calculating the Mean, standard and other measures.

Based on table 3 the Mean and Standard deviation of learners' marks in each group were classified.

Table 3. Comparison of statistical calculations of both teachers

\begin{tabular}{|c|c|c|c|c|c|c|}
\hline $\begin{array}{l}\text { the number of the words that the learners have known their mea } \\
\text { the effect of lexicon teaching beliefs in male and female learners }\end{array}$ & Mean & $\mathbf{N}$ & Std. Deviation & Minimum & Maximum & Sum \\
\hline function-based lexicon teaching belief & 39.62 & 50 & 1.497 & 35 & 41 & 1981 \\
\hline memory-based lexicon teaching belief & 24.44 & 50 & 6.088 & 12 & 38 & 1222 \\
\hline Total & 33.53 & 100 & 7.585 & 12 & 41 & 3203 \\
\hline
\end{tabular}

In table 3 it was shown that the mean of the scores for learners in Function-Based teaching is higher than those in the Memory-Based group (Function-Based mean=39.62 out of 42 words; Memory-Based group mean=24.44 out of 42 words) considering that the Function-Based group of learners provided correct meanings for 94.33 percent of that words that were given to them whereas the MemoryBased group of learners provided only 61.1 percent of correct answers.

\section{Implication of the Results}

As it was stated previously the aim of this research was to find the relationship between teacher beliefs and learners' promotion in lexicon intake. The null hypothesis of the study was "There are no differences between lexicon teaching beliefs in promoting learners' lexical intake." Based on the results, since the $t$ value of 12.936 exceeds the $\mathrm{t}$ critical value of 2.617 at the .01 level of significance; the null hypothesis is rejected (see table 4).

Table 4. Independent Sample T-test

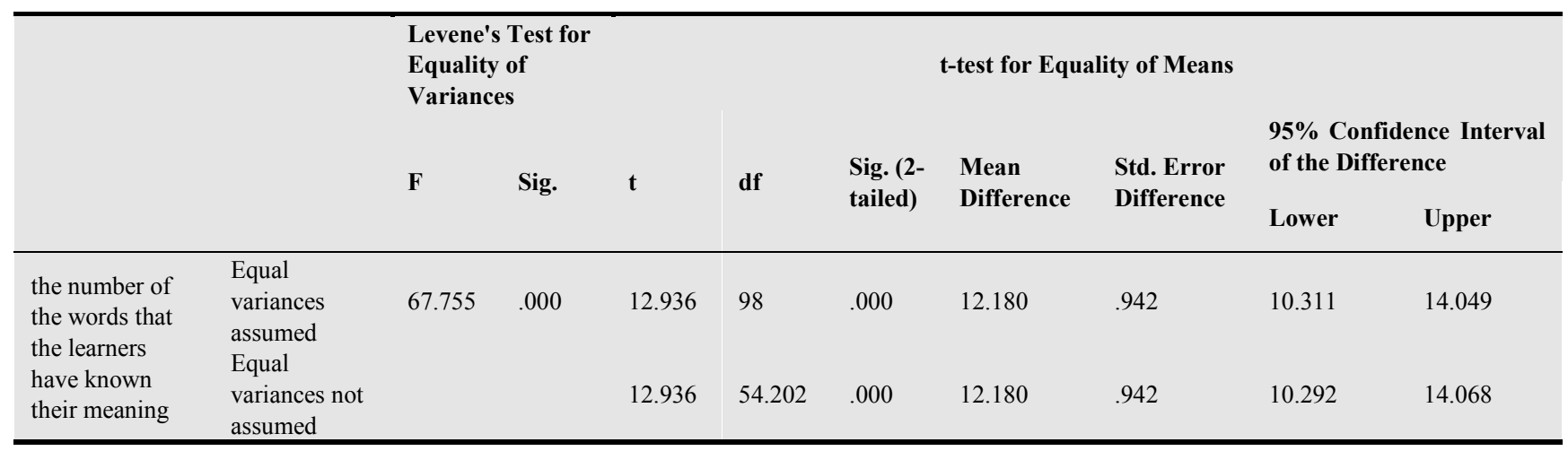


In other words for the entire population of 100 learners the results were $t$ equal to 12.936 , df equal to 98 with $99 \%$ confidence interval. Based on these results, it is possible to conclude that the learners who were taught by the teacher with higher number of function-based lexicon teaching beliefs had better results in the vocabulary test than those who were taught by the one with a higher number of Memory-Based beliefs. The result was the same for both genders. These findings correspond to other studies in language teaching in that they show that "language teachers' classroom practices are shaped by a wide range of interacting and often conflicting beliefs" (Borg, 2003: 91; also Zheng, 2009; Cohen \& Fass, 2001).

But this research aimed at examining more carefully the influence of teachers' beliefs on learners' lexicon intakes, the important area which had little or no special attention in previous researches. The research is focused on teachers' beliefs about teaching vocabulary and the result may assist teacher educators in providing useful knowledge about the development of vocabulary methods and strategies courses in Teacher training centers. According to the findings of the data it is possible to say that the Function-Based approach to vocabulary teaching promotes better lexicon intake.

Being conscious about teacher/teaching beliefs can be helpful in promoting more effective teaching approaches. So It is discussed in this paper that teachers' beliefs in effective teaching approaches of lexicon will lead to better strategies, and consequently resulting in more learners with better scores in enhancing vocabulary learning.

\section{Limitations}

This study investigates just two aspects of lexicon teaching beliefs (Mem-B and F-B) based on teachers' statements in writing forms. Perhaps there were other kinds of beliefs in their minds which have powerful effect on learning and the teachers themselves have not stated them or some new beliefs may create in their minds while teaching. And it is the problems that most mental researches confront with it because mental aspects such as belief are abstract concepts, and the solely source for measuring it is what people themselves have stated. And the researchers had no control over metal changes which will occur during experiment. It is the same for researches which are about different beliefs. As Ghaffarzadeh (b) (2012) had stated "beliefs are changeable; they can be added, omitted or modified during teaching and learning". So, there is the possibility of omitting, modifying or adding some new ideas concerning teaching vocabulary which may have powerful effects on learning and not be seen by the researcher. These are the problems that may effect on the results. The problems may be limited, if it was done in a longitudinal study, but it wasn't possible because of time limitations and the special conditions of Iranian schools.

As Best \& Kahn(2000:119) explained in these kinds of studies the researcher cannot control that condition and similarly, in this study, there is no control on teachers' beliefs; the researcher can just monitor its probable effect on learning. There is no treatment here and just an observation of the environment (Ghaffarzadeh (b), 2012). This research is a kind of casual-comparative research. The independent variable (beliefs) has already been completed and the researcher cannot manipulate it (Best \& Kahn, 2000). The researcher just wants to measure the influence of what is in teachers' minds on students' vocabulary intake and the unique procedure to access to it is their own statements. But even their statements are exactly based on what are in their minds, they may innovate while teaching, they can create new strategies, and consequently new beliefs may emerge in their minds. So, it is necessary to triangulate with factors that go beyond measurement in humanistic studies on as teaching beliefs (Ghaffarzadeh, 2012).

\section{Suggestions for Further Study}

If it is possible to do a longitudinal study of teacher belief development the limitations which explained in part7 will be decreased notably. This study attempted to identify the effects of beliefs on vocabulary, further researches can be done to explore the development of teachers' beliefs in other areas of learning a language. Moreover, other kinds of beliefs can be seen as profitable research areas in learning/teaching languages field.

\section{Acknowledgments}

I wish to express my gratitude firstly to merciful God, then to the Iranian EFL teachers and learners in this study, especially my own students. Most of all, I have been fortunate in having some precise comments from some research experts such as Professors Norbert Schmitt, Jack. C. Richards, Noam Chomsky, and Paul Nation who helped me in solving research problems via E-mail. Thanks are also due to my professor, Dr Shahrokh Jahandar, and my dear father and brother who encouraged me during the research, especially my brother who help me in conducting the methodology.

\section{Notes}

a. Third year of learning English as foreign language for learners in Iran who are about 14 years old.

b. Original Proficiency test to test the learners' proficiency level in English

c. Determining sample size for research activities educational measurement. (1970). Based on the table the sample will be around 100 subjects from 150 persons in statistical community. 


\section{Appendix A}

\section{Questionnaire on Teachers' Beliefs about "Teaching Vocabulary"}

This questionnaire is an attempt to gather information about Iranian English teachers' beliefs about teaching vocabulary. Your ideas are highly valued and your cooperation genuinely appreciated. The data gathered just serves this research and will remain confidential. Please feel free to share your ideas when answering the following items. If you are interested in the results of this survey, please leave your e-mail address in the end. A copy of the results will be sent to you afterwards.

\section{Part A: Personal Information}

Your name:

Your age: ...............

1. How many years have you taught English? year (s)

2. Have you received any training on how to teach vocabulary learning strategies?

Yes (Please specify what type of training: ) No

\section{Part B: Close-Ended Questions}

$<$ Instructions $>$ for each statement, there is one scale for you to place a tick. The following scale is for you to specify how useful you consider the strategy is to your students.

The scale

\begin{tabular}{|c|c|c|c|c|c|c|c|c|}
\hline quite useful & Useful & Moderately useful & Slightly useful & & \multicolumn{3}{|c|}{ not at all useful } & \\
\hline 5 & 4 & 3 & 2 & & & & & \\
\hline Number & Belief description & & & 1 & 2 & 3 & 4 & 5 \\
\hline 1 & $\begin{array}{l}\text { To connect a word to a } p \\
\text { to a memory of playing in }\end{array}$ & $\begin{array}{l}\text { remember it. (e.g. Cc } \\
\text { time) }\end{array}$ & the word snow & & & & & \\
\hline 2 & To connect a word to its s & ss to remember it. & & & & & & \\
\hline 3 & To use new words in sent & & & & & & & \\
\hline 4 & To group words together & member them. & & & & & & \\
\hline 5 & $\begin{array}{l}\text { To use Keyword Method } \\
\text { It means to find some } \mathrm{w} \\
\text { teach and make an imagin }\end{array}$ & $\begin{array}{l}\text { ounds like the Engli } \\
\text { rs' minds to remembe }\end{array}$ & that we want to & & & & & \\
\hline 6 & To repeat a word aloud to & a word. & & & & & & \\
\hline 7 & To write a word repeatedl & & & & & & & \\
\hline 8 & To imagine the written fo & hber it. & & & & & & \\
\hline 9 & $\begin{array}{l}\text { To use physical action } \\
\text { memory. }\end{array}$ & Response) when lear & ord to enhance & & & & & \\
\hline 10 & To listen to tapes/CDs of & & & & & & & \\
\hline 11 & To keep a vocabulary not & vocabularies. & & & & & & \\
\hline 12 & $\begin{array}{l}\text { To concentrate on analyz } \\
\text { first step. }\end{array}$ & (e.g. noun/verb) of a & wn word for the & & & & & \\
\hline 13 & $\begin{array}{l}\text { To make use of common } \\
\text { unknown word. }\end{array}$ & of the world when gu & meaning of an & & & & & \\
\hline 14 & Using the whole text to ur & words & & & & & & \\
\hline 15 & Replace the unknown wo & $\mathrm{ng}$ to check if the sen & kes sense. & & & & & \\
\hline 16 & To analyze affixes and ro & rd in an early stage wl & ing. & & & & & \\
\hline 17 & To remember the most co & & & & & & & \\
\hline 18 & Using extensive reading $\mathrm{f}$ & or magazines. & & & & & & \\
\hline 19 & Study the relation betwee & ciation of a word. & & & & & & \\
\hline 20 & Study a word with other 1 & lar pronunciation & & & & & & \\
\hline 21 & Deliberately study a voca & & & & & & & \\
\hline 22 & Use words in real-life situ & & & & & & & \\
\hline 23 & Self-testing. & & & & & & & \\
\hline 24 & Use mnemonics to remem & & & & & & & \\
\hline 25 & Explain example sentence & & & & & & & \\
\hline 26 & Request students to make & w word. & & & & & & \\
\hline
\end{tabular}

$* * *$ Note: The scales are: $(1=$ not at all useful $2=$ slightly useful $3=$ moderately useful $4=$ quite useful $5=$ quite useful $)$

** If you are interested in the results, please leave your email: 


\section{Appendix B}

\section{The Details for Pilot Study}

\begin{tabular}{|c|c|c|c|c|}
\hline $\begin{array}{l}\text { Final study subjects(learners) } \\
\text { NO. } 100\end{array}$ & $\begin{array}{l}\text { Pilot study subjects(learners) } \\
\text { NO. } 15\end{array}$ & $\begin{array}{l}\text { Final stud } \\
\text { NO. } 4 \text { out }\end{array}$ & (teachers) & $\begin{array}{l}\text { pilot study subjects(teachers) } \\
\text { NO. } 2 \text { out of } 4\end{array}$ \\
\hline $\begin{array}{l}50=\text { Mem-B } \\
50=\text { F-B }\end{array}$ & $\begin{array}{l}8=\text { Mem-B } \\
8=\text { F-B }\end{array}$ & $\begin{array}{l}1=\text { Mem-B } \\
1=\text { F-B }\end{array}$ & $\begin{array}{l}50 \text { learners for } \\
\text { each teacher }\end{array}$ & $\begin{array}{l}1=\text { Mem-B } \\
1=F-B\end{array}$ \\
\hline
\end{tabular}

\section{References}

[1] Allen, V. F. (1983). Techniques in teaching vocabulary. Oxford: Oxford University Press.

[2] Allison, B., O’Sullivan, T., Owen, A., Rice, J., Rothwell, A.,\& Saunders, C. (1996). Research skills for students. London: Kegan Paul.

[3] Anderson, L., \& Bird, T. (1995). How three prospective teachers construed three cases of teaching. Teaching \& Teacher Education, 11(5), 479-499.

[4] Beck, I. L., McKeown, M. G., \& Kucan, L. (2002). Bringing words to life: Robust vocabulary instruction. New York: Guilford.

[5] Best,W.J and Kahn,V. J. (2000).Research in education.(10 ${ }^{\text {th }}$ Ed.).Pearson education Inc:118-119

[6] Borg, S. (2003). Teacher cognition in language teaching: A review of research on what language teachers think, know, believe, and do. Language Teaching, 36: 91. Retrieved 14 September 2012 from: http://journals.cambridge.org/action/displayAbstract?fromPa $\mathrm{ge}=$ online\&aid=151137.http://dx.doi.org/10.1017/S0261444 803001903

[7] Borg, S. (2012). Interview: Teacher cognition and language teacher education: Beliefs and practice. A conversation with Simon Borg. Interview by M. Birello. Bellaterra Journal of teaching \& Learning Language \& Literature, 5(2), 88-94.

[8] Borko, H., Eisenhart, M., Brown, C. A. et al. (1992). Learning to teach hard mathematics: Do novice teachers and their instructors give up too easily? Journal for Research in Mathematics Education, 23, 194-222.

[9] Brand, B., \& Wilkins, J. (2007). Using self-efficacy as a construct for evaluating science and mathematics methods courses. Journal of Science Teacher Education, 18(2), $297-$ 317. Retrieved 15 September 2012 from: http://www.citeulike.org/journal/klu-jste/. http://dx.doi.org/ 10.1007/s10972-007-9038-7

[10] Brookhart, S. M., \& Freeman, D. J. (1992).Characteristics of entering teacher candidates. Review of Educational Research, 62(1), 37-60. Retrieved 12 September 2012 from: $\mathrm{http} / /$ www.jstor.org/action/doBasicSearch?filter $=\& Q$ uery $=$ $\&$ Search. $x=5 \&$ Search. $y=8 \& w c=0$ on

[11] Brown, T. S. \& Perry. F. L. (1991). A comparison of three learning strategies for ESL vocabulary acquisition. TESOL Quarterly; 25: 655-670. http://dx.doi.org /10.2307/3587081
[12] Calderhead, J. (1991). The nature and growth of knowledge in student teaching. Teaching and Teacher Education, 7(5/6), 531-35.

[13] Calderhead, J., \& Robson, M. (1991). Images of teaching: Student teachers' early conceptions of classroom practice. Teaching and Teacher Education, 7(1), 1-8.

[14] Chan, K., \& Elliot, R. (2004).Relational analysis of personal epistemology and conceptions about teaching and learning. Teaching and Teacher Education, 20, 817-831. http://dx.doi.org/10.1016/j.tate.2004.09.002

[15] Cohen, A. D., \& Fass, L. (2001). Oral language instruction: Teacher and learner beliefs and the reality in EFL classes at a Colombian University. Research report. Department of English and Second Language, University of Minnesota, February 2001.

[16] Cummins, J. (1994). The acquisition of English as a second language. In K. Spangenberg-Urbschat \& R. Pritchard (Eds.) Kids come in all languages: Reading instruction for ESL students (pp. 36-62). Newark, DE: International Reading Association.

[17] Dornyei, Z. (2003). Questionnaires in second language research: Construction, administration, and processing. London: Lawrence Erlbaum.

[18] Ghaffarzadeh Hassankiadeh, M. A .(a). 2012. The effect of teachers' lexicon teaching beliefs on EFL learners' vocabulary Intake. Journal of Education and Learning, 1(2):156-160. http://dx.doi.org/10.5539/jel.v1n2p

[19] Ghaffarzadeh Hassankiadeh, M.,A.(b). 2012. Functionbased V.S Meaning-based beliefs in teaching vocabulary. Bellaterra Journal of Teaching \& Learning Language \& Literature.5(4):

http://revistes.uab.cat/jtl3/article/view/483/551

$20-41$.

[20] Gu, P.Y. (2003). Fine brush and freehand: the vocabularylearning art of two successful Chinese EFL learners. TESOL Quarterly, 37(1): 73-104. http://dx.doi.org /DOI: $10.2307 / 3588466$

[21] Gu, P. Y. (2005). Vocabulary learning strategies in the Chinese EFL context. Singapore: Marshall Cavendish.

[22] Harrison, A. (1983). A Language testing handbook. London \& Basingstoke: Macmillan Press Ltd.

[23] Holt-Reynolds, D. (1992). Personal history-based beliefs as relevant prior knowledge in coursework. American Educational Research Journal; 29(2): 325-349. Retrieved 5 September 2012 from: http://www.deepdyve.com/lp/sage/personal-history-basedbeliefs-as-relevant-prior-knowledge-in-courseZxdT1ZXsMc 
[24] Horwitz, E.K., (1985). Using student beliefs about language learning and teaching in the foreign language methods course. Foreign Language Annals; 18(4): 333-340. http://dx.doi.org/ 10.1111/j.1944-9720.1985.tb01811.x

[25] Kagan, D. M. (1992). Implication of research on teacher belief. Educational psychologist, 27(1), 65. http://dx.doi.org /10.1207/s15326985ep2701_6

[26] Laufer, B. (1986). Possible changes in attitude towards vocabulary acquisition research. International Review of Applied Linguistics in Language Teaching, 24, 69-75.

[27] Milner, H. R. (2005). Stability and change in US prospective teachers' beliefs and decisions about diversity and learning to teach. Teaching and Teacher Education, 21(7), 767-786. Retrieved from: http://www.sciencedirect.com/science/article/pii/S0742051X 05000697. http://dx.doi.org/10.1016/j.tate.2005.05.010

[28] Minor, L.C., Onwuegbuzie, A.J., Witcher, A.E., \& James, T.L. (2001, November).Trends in teacher candidates educational beliefs. Paper presented at the Annual Meeting of the Mid-south Educational Research Association, Little Rock, AR.

[29] Nation, I. S. P. (1990).Teaching and learning vocabulary. Boston, MA: Heinle \& Heinle.

[30] National Reading Panel. (2000). Report of the national reading panel: Teaching children to read. Washington, D.C.: National Institute of Child Health and Human Development.

[31] Ozgun-Koca, S. A., \& Sen, A. I. (2006). The beliefs and perceptions of pre-service teachers enrolled in a subject-area dominant teacher education program about "effective education. Teaching and Teacher Education, 22(7):946960.Retrieved $10 \quad$ September 2012 from: http://www.sciencedirect.com/science/article/pii/S0742051X 06000692.http://dx.doi.org/10.1016/j.tate.2006.04.036

[32] Pajares, M. F. (1992). Teachers' beliefs and educational research. Review of Educational Research, 62(3): 307-332. Retrieved $10 \quad$ September 2012 from: http://www.jstor.org/action/doBasicSearch?filter=\&Query= $\&$ Search $. x=5 \&$ Search $. y=8 \& w c=0$ n

[33] Pajares, F. (1993). Preservice teacher beliefs: A focus for teacher education. Action in Teacher Education, 15(2), 4554.
[34] Palmer, D. (2006). Durability of changes in self-efficacy of pre service primary teachers. International Journal of Science Education, 28(6), 655-671. Retrieved 12 September 2012 from :http://www.tandfonline.com/toc/tsed20/28/6/. http://dx.doi.org/10.1080/09500690500404599

[35] Pohan, C., \& Adams, C. (2007). Increasing family involvement and cultural understanding through a university school partnership. Action in Teacher Education, 29(1), 4250. Retrieved 15 September 2012 from: http://www.tandfonline.com/doi/abs/10.1080/01626620.200 7.10463438.http://dx.doi.org/10.1080/01626620.2007.10463 438

[36] Richards, J. C. (1980). The role of vocabulary teaching. In K Croft (Ed.), Readings in English as a second language: For teachers and teacher trainers, 2nd ed. (pp. 424-438). Cambridge, MA: Winthrop.

[37] Richardson, V. (1996). The role of attitudes and beliefs in learning to teach. In J. Sikula (Ed.), Handbook of research on teacher education. New York: Macmillan Library Reference USA, and Simon \& Schuster Macmillan.

[38] Rifkin, B. (2000). Revising beliefs about foreign language learning. Foreign Language Annals, 33(4): 394-420. http://dx.doi.org /10.1111/j.1944-9720.2000.tb00621

[39] Schmitt, N. (2000). Vocabulary in language teaching. Cambridge: Cambridge University Press.

[40] Smith, M. K. (1941). Measurement of the size of general English vocabulary through the elementary grades and high school. Genetic Psychological Monographs, 24, 311-345.

[41] Torff, B. (2003). Developmental changes in teachers' use of higher-order thinking and content knowledge. Journal of Educational Psychology, 95(3), 563-569. Retrieved 12 September 2012 from: http://psycnet.apa.org/journals/edu/95/3/563/. http://dx.doi.org /10.1037/0022-0663.95.3.563

[42] Wubbels, T. (1992). Taking account of student teachers' preconceptions. Teaching and Teacher Education, 8, 137-49.

[43] Zheng, H. (2009). A review of research on EFL pre-service teachers' beliefs and practices. Journal of Cambridge Studies; 4.(1): 79.Retrived 10 September 2012 from: http://journal.acs-cam.org.uk/ 